DOI 10.31558/2075-2970.2019.38.3

УДК 316.77:811.161.2

ORCID ID: 0000-0002-9109-2689

ORCID ID: 0000-0003-0783-6540

ORCID ID: 0000-0001-6222-039X

ORCID ID: 0000-0002-5857-6120

(C) А. А. Гребенюк, Т. Г. Демчук,

А. В. Савицька, Н. В. Стрюк

(м. Вінниця)

\title{
ІРОНІЯ ЯК ФІЛОСОФСЬКО-ЕСТЕТИЧНЕ ЯВИЩЕ СЕРЕД ІНШИХ МОВНИХ ЗАСОБІВ КОМІЧНОГО
}

\begin{abstract}
Анотація. У статті розглянуто іронію та диференційні ознаки іронії як філософсько-естетичної та лінгвістичної категорії. Наразі цей феномен представляє цікавість для лінгвістичного дослідження, хоча коло лінгвістичних та екстралінгвістичні досліджень за темою є дещо обмеженим. Отже, різноманітні аспекти засобів лінгвістичної оцінки, включаючи іронію як один із засобів створення комічного ефекту, набувають особливої значущості та потрапляють у фокус лінгвістичних та культурологічних наукових розвідок.

Із давніх часів, питання створення комічного ефекту приваблювало не тільки митців (письменників, художників, митців), але і науковців (філософів, антропологів, психологів, логіків та лінгвістів). Відчуття комічного очевидно пов'язане із відчуттям задоволення, яке виникає у комбінації несумісних понять або порушення природного ходу речей; саме це дисонанс, який спочатку сприймається як серйозний або навіть небезпечний, виявляється абсолютно безпечним. Іронія - спеціальний засіб створення комічного ефекту, який може мати різноманіття зворотних реакцій: від сміху до образи та зневаги. Ступінь вираження цієї реакції залежить не тільки від наявності / відсутності почуття гумору, але і від особистих рис слухача / читача.

Іронія - це комплексний і дещо суперечливий феномен, адже у соціальній свідомості мовців 3 точки зору норм та правил суспільної поведінки вона залишає по собі певний негативний ефект. Але у той самий час іронія $є$ дуже привабливою для мовців через те, що приносить певне задоволення тим, хто нею користується.

Ключові слова: іронія, комізм, гумор, сатира, засоби комічного, мовленнєві засоби, лінгвокультурологія, смішне, універсальна іронізація.

Anzhelika Grebenyuk, Tetiana Demchuk, Anastasiia Savytska, Natalia Striuk IRONY AS A PHILOSOPHYCAL AND AESTHETIC PHENOMENON AMONG OTHER LINGUISTIC MEANS OF COMIC
\end{abstract}

Abstract. The article looks into the irony and various characteristics of irony as a philosophic and aesthetic, but at the same time linguistic category. Presently it poses high interest for a linguistic research, though linguistic and extralinguistic studies concentrating on this language means are not numerous. Thus, various aspects of evaluative language means, including those of irony as one of the means of creating comic effect, acquire special significance and appear in the focus of linguistic and cultural studies.

From ancient times, the issue of comic attracted not only different cultural figures, namely writers, artists, and painters, but also scholars - philosophers, anthropologists, psychologists, logicians, and linguists. A sense of comic is believed to be connected with a sense of pleasure which arises from an unexpected disappearance, the removal of the opposite feeling; it manifests itself in unexpected combination of incompatible 
notions or natural order disturbance, and this dissonance, which is initially perceived as serious and dangerous, is soon found to be completely harmless. Irony is a special means of creating comic effect which can have a variety of reciprocal reactions - from laughter to insult and indignation. The degree of expression of this reaction depends not only on the presence or absence of the listener's sense of humor, evidently other personal traits of the listener / reader are quite important too.

So, irony is a complex and contradictory phenomenon. In the social consciousness, from the point of view of norms and rules of behavior, it still involves certain negative effect. At the same time, it is very attractive to people and brings great satisfaction to those who use it.

Key words: irony, language means, linguistic and cultural studies, extra lingual factors, comic element, humor, satire, universal irony.

\section{1. Вступ}

«Почуття комічного - це почуття задоволення, яке виникає через несподіване зникнення, зняття протилежного почуття; воно виявляється внаслідок несподіваного поєднання непоєднуваного чи порушення природного порядку речей за умови, що це порушення, яке спочатку сприймається як серйозне і небезпечне, невдовзі виявляється цілком нешкідливим» (Арутюнова, 2007, с. 5).

Тема комізму і комедії від прадавніх часів привертала до себе увагу не лише різних культурних діячів, а саме письменників, артистів і художників, але також і вчених - філологів, філософів, антропологів, психологів і логіків.

Слово ‘комізм’ походить від грец. комос, що означає «ватагу, натовп виряджених людей» на святах, присвячених богу родючості, рослинництва, виноградарства і виноробства Діонісію (або Вакху) в Греції. Саме слово «комедія» часто розшифровують як «пісні Комоса», що в свою чергу означає ритуальну ходу в Стародавній Греції в музичному супроводі кіфар і флейт, для якої була характерна фривольність і невимушеність. Інакше кажучи, комізм асоціювався 3 карнавальними іграми, часто жорстокими, де кожна людина мала стати учасником дійства, а не просто спостерігачем.

Вважається, що ще одним ймовірним джерелом сміхової культури стали «римські сатурналії» - тобто свята на честь Сатурна, бога землеробства. Під час таких сатурналій люди віддавалися несамовитим веселощам і пияцтву.

Відчуття комічного - це властивість, яка притаманна кожній людині, що визначається іноді як «homo ridens» «людина яка сміється». Ця ознака робить людину унікальним створінням, виділяє її у світі тварин, хоча сьогодні вважається, що приматам також уже був знайомий сміх. Сміх є спонтанним і хаотичним. Сміх порівнюють з вигуками, тобто він виражає безпосередній відгук на зовнішні подразники так само, як і вигук «Wow!» від раптового подиву. Але поступово до звичайних звуків, які виникали спонтанно і мимоволі почали приєднуватись й інші різні значення і функції, спочатку прості, а потім все більш витончені і суперечливі (Арутюнова, 2007, с. 6).

Комічне належить до найважливіших концептів будь-якої національної культури, тому його вираження у мовній семантиці та прагматиці відзначається різноманітністю форм. Відповідно, теорії комічного, яка визначає його природу, специфіку функціонування, диференцію його типів, присвячено багато фундаментальних праць. О. Калита відмічає наступні моделі теорій комічного, які існують за Б. Дземідок:

1) теорія негативної якості (Аристотель, Т. Гоббс, К. Уберхост); 
2) теорія деградації (А. Бейн);

3) теорія контрасту (Т. Ліппс, Г. Спенсер, Ж. Поль);

4) теорія протиріччя (А. Шопенгауер, Г. Гегель);

5) теорія відхилення від норми (К. Гросс, Е. Обуе);

6) теорія мотивів, що перетинаються (А. Бергсон, 3. Фройд, А. Луначарський) (Калита, 2013, c. 14).

Учені пояснюють комічне або через якості самого об'єкта комічного бачення, або ж через особливості реакції суб'єкта (Калита, 2013, с. 11). До теорій першого типу, вихідним положенням якого стала констатація незвичайних характеристик комічного, що притаманна об’єкту, належать теорії контрасту, невідповідності, протиріччя, теорія помилки і т. ін. Теорії другого типу уособлюють пояснення, які саме почуття виникають у людини при іiі реакції на комічне, які емоції переживаються суб'єктом чи який психічний стан приховуються за реакцією сміху на ту чи іншу ситуацію. Основні думки, що підпадають під цю групу пояснень комічного зводяться до того, що в основі сміхової реакції людини лежить почуття переваги, що сміх є синтезом радості і злості, або що він $є$ розрядкою від напруги. Сюди належать теорії несподіванки («невиправданого сподівання»), новизни, захисної реакції (З. Фройд), комічного як «високого навиворіт» (Жан Поль), розсіювання ілюзії, надлишку психічної енергії (Ф. Ніцше), зустрічі душі з «ніщо» (І. Кант) (Калита, 2013, с. 13).

До теорій першого типу комічного відносять особливості його трактування А. Шопенгауером, який вважав, що джерелом будь-якої невідповідності є розбіжності між реальним світом і нашим уявленням про нього. А в самій свідомості ця невідповідність може відображатися як переживання комічної невідповідності між абстрактним загальним уявленням i конкретним явищем, між поняттям і реальністю, між формою і сутністю речей, загальноприйнятим і унікальним (Калита, 2013, с. 13).

До теорій другого типу належить гіпотеза Ф. Ніцше, який стверджував, що сміх - це вивільнення життєвої енергії, коли ми раптом усвідомлюємо: те, що загрожувало нам і викликало у нас відчуття страху, насправді не є страшним і не становить для нас загрози (Калита, 2013, с. 15).

Зовсім нову теорію, яка потім лягла в основу багатьох інших, запропонував А. Бергсон. Головним в його концепції є постулат про соціальну природу комічного. За його словами комічне виникає тільки в людському суспільстві, натомість природа не може бути комічною сама по собі (Калита, 2013, с. 15).

О. Калита за теорією В. Саннікова слушно вважає, що кожна 3 цих теорій містить раціональне зерно. Якщо розглядати їх не як завершені всеосяжні теорії - на що безумовно претендують їх автори, а розцінювати їх лише як розробки окремих положень, окремих сторін комічного, то «все стає на свої місця, і замість хаотичного нагромадження теорій, які взаємно виключають одна одну, виникає чітке розуміння сутності комічного» (Калита, 2013, с. 18).

Узагальнення цих теорій відображене у визначенні Ю. Борєва, де комічне - це «суспільно значуще життєве протиріччя (мети - засобам, форми - змісту, дії- обставинам, сутності iï проявам, причини - наслідкам, дії - результатам, старого - новому, реальності - уявленням про неї і т. ін.), яке в мистецтві виступає об'єктом особливої емоційно насиченої естетичної критики - осміяння» (Калита, 2013, с. 18). Реакцією на комічне є, як правило, сміх - наслідок комічних слів чи поведінки, їх так званий «перлокутивний ефект». 


\section{2. Виклад основного матеріалу}

2.1. Теоретичні засади дослідження. В наші дні сміх зазвичай асоціюється з веселощами і оцінюється позитивно. Щоб викликати сміх і самому посміятися, люди жартують, розповідають анекдоти, дивляться комедії, слухають оперети, ходять в цирк. Тим часом сам сміх і особливо регіт в своїй звуковій та зримій реалізації, абстрактній від змісту, не є естетичним. Сміх спотворює як вигляд людини, так і звук, яким виражається сміхова реакція. Особливо непривабливо виглядає застигле, нерухоме, позбавлене будь-якої динаміки зображення обличчя людини, яка регоче. Такий статичний вираз обличчя відштовхує навіть портретистів. Однак амбівалентність сміху добре передається в жанровому живописі та в літературі. Дивовижно, на скільки змінюється сприйняття друкованого опису людини, яка сміється, від простого споглядання. У читача втрачається візуальний аспект розуміння ситуації, тому там, де мало б виникнути негативне відчуття або відраза, виникає позитивне відношення до об'єкта, що сміється саме через втрату візуалізації цієї дії.

У безпосередньому спостереженні не естетичні образ і звук сміху і навіть зміст комічного, але вони все ж таки здатні викликати приємне відчуття в душі і настрої людини, яка сміється. Отже, сміх, на відміну від посмішки, сприймається і слухом і зором. Але і в тому і в іншому випадку сміх далеко не завжди прикрашає людину (Шатуновський, 2007, с. 340).

Значення феномену сміху в житті людства постійно коливалося. У статті «Іронія» (1908) О. Блок назвав сміх хворобою століття: «Ця хвороба - той самий душевний недуг ... Ї̈̈ прояви - напади виснажливого сміху, який починається 3 диявольськи-знущальної, провокаторської посмішки, а закінчується - дикістю і блюзнірством» (Шатуновський, 2007, с. 340).

Тепер зупинимося дуже коротко ще на одній особливості сміху, а саме на його «не поодинокості», що має наслідки. Сміх в своєму джерелі- це форма дотику і взаємодії людей. Сміх виникає у формі діалогу: Звуки сміху супроводжують висловлюваннями, надаючи їм додаткові смисли, і можуть бути також еквівалентні репліці. Парність сміху надавала йому аналогію з любовною «грою». Вважається навіть, що звуки сміху можуть бути ототожнені з сексуальною «музикою».

Доречно нагадати, що комізм повинен бути не тільки яскравим або витонченим, він вимагає артистизму у виконанні. Виконавець комічного тексту повинен вміти вуалювати двозначність, надаючи слухачеві самому провести зіставлення пародії з оригіналом, способу з натурою. А вже такі тонкі уособлення і прийоми є характерними ознаками зовсім іншого виду комічного - іронії.

2.2. Залежно від емоційного наповнення і наявності раціонально-оцінного компонента виділяють два основні типи комізму: простий (елементарний) і складний (Воробйова, 2007, с. 201).

Складний комізм обов'язково спонукає до аналізу і роздумів, він містить оцінку, яка грунтується на суспільному досвіді, вироблених суспільством ідеалах і цінностях. У його основі, зазвичай, лежить стійке протиріччя, зумовлене не зовнішніми, поверховими причинами, а природою явища чи факту (Воробйова, 2007, с. 201).

У межах складного комізму традиційно виділяють основні форми комічного: сатиру, гумор та іронію, в основі розрізнення яких лежить критерій ставлення до об'єкта комічного. Так, гумор - це форма комічного, у якій висміюються окремі сторони об'єкта чи явища, але при цьому їхня привабливість зберігається. На відміну від гумору, сатира полягає в гострому осудливому висміюванні негативного, заперечуючи недосконалість світу в ім'я його докорін- 
ної зміни відповідно до ідеалу. Іронія - це рівноправна форма комічного, нарівні із сатирою та гумором, визначальною рисою якої є глибока інтелектуальність, насмішкувате ставлення до об'єкта зображення, яке грунтується на почутті переваги мовця над предметом мовлення. При цьому більшість дослідників зазначають, що чітко визначених, непроникних меж між типами i формами комічного не існує, вони часто переходять один в одного, змішуються, створюючи нові форми і відтінки комічного (Воробйова, 2007, с. 202).

2.3. Можна виділити два аспекти вивчення іронії: філософсько-естетичний, який тлумачить іронію широко, як один із компонентів категорії комічного, і лінгвістичний, який розглядає іронію як стилістичну категорію, що функціонує у межах художнього тексту.

Для того, щоб з'ясувати лінгвістичну суть іронії необхідно насамперед визначити її статус як філософсько-естетичного феномена, ï місце серед таких понять, як гумор, сатира, комічне, трагічне, і дослідити специфіку іiі проявів. Це завдання є складним через те, що упродовж різних історичних періодів провідного значення набував той чи інший різновид іронії: в Античності - трагічна іронія, у добу Відродження - насмішкувата, у романтиків та їх послідовників - песимістична та нігілістична (Воробйова, 2007, с. 202). Цим зумовлюються і розходження в поясненні філософсько-естетичної ії суті. Можна виділити такі підходи до тлумачення іронії: це форма діалектичного мислення, яка відображає протиріччя історичного процесу (Г.-Ф. Гегель); це спосіб соціальної критики (А. Герцен); це інструмент виявлення протиріччя між ідеалом і дійсністю (О. Блок); це спосіб вираження розчарування і цинізму (Ф. Ніцше); це форма тотального заперечення (екзистенціалісти, постмодерністи) (Воробйова, 2007, с. 204).

Звичайно ж, іронія має багато спільного з гумором, але ці поняття не слід змішувати. Гумор завжди викликає сміх. Смішне - це несподіване зіткнення між позитивним і негативним. В цьому відношенні іронія схожа з гумором. Однак функція іронії не обмежується створенням комічного ефекту. «Іронія може не містити ні тіні гумору, виражаючи роздратування, обурення, гіркоту, неприязнь і інші почуття, вельми далекі від бажання жартувати» (Воробйова, 2007, c. 203).

2.4. Уявлення людини про навколишній світ, його ставлення до життя і усвідомлення своєї ролі в ній поступово змінювалися з розвитком суспільства, в якому вона жила, а отже, змінювався і спосіб мислити і висловлювати свою думку. Так, філософський підхід древніх греків відобразився на їхньому розумінні іронії як філософсько-логічного прийому. Риторика - чи не найважливіша з грецьких наук, яка займала також одне з провідних місць в системі середньовічної освіти, зіграла велику роль у визначенні іронії як риторичного прийому в Середні віки. Свобода від недосконалості дійсності стала найвищою цінністю романтичного суспільства, а такий принцип відношення до реальності вимагав «універсальної іронізації»тобто установки на те, що митець повинен брати під сумнів як реальні предмети і явища, та $\mathrm{i}$ свої власні судження про них. Звідси виникає питання про іронію як змістовну категорію, яка $\epsilon$ пов'язаною з світоглядом і естетикою авторів. I нарешті, XX століття розглядає «епічну іронію» як найбільш широкий і вільний від будь-якого моралізаторства погляд на дійсність, що призводить до розуміння іронії як іронічного бачення світу на початку XXI століття (Воробйова, 2007, с. 206).

Іронія як змістовна категорія, певним чином пов'язана з пануючими у відповідну епоху філософськими, політичними та етичними течіями, з світоглядом і естетичними смаками авторів. Спосіб життя певної країни і людей, і умови, в яких існує література, створюють певний 
тип людини, що іронізує - іроніста, а також певні способи іронізації. «Іронія не суто мовне явище, вона певною мірою обумовлена менталітетом, національним характером, індивідуальним темпераментом та іншими факторами» (Воробйова, 2007, с. 204).

Прояви іронії в мистецтві характеризуються деякою складністю, яка в дійсності визначає особливості займаного іронією положення в структурі комічного. Узагальнюючим та об'єднуючим стрижнем усіх компонентів категорії комічного є сміх, джерела якого різні за характером і напрямком. У цьому полягає основа поділу структури загальної категорії комічного на форми та способи вираження - пародію, бурлеск, гротеск, з одного боку, і на гумор, іронію, сатиру як види емоційно-ціннісного ставлення до дійсності, з іншого (Воробйова, 2007, с. 204).

Багато дослідників прагнуть розмежувати іронію, гумор і сатиру. Вважається, що гумор і сатира - полюси сміху, а між ними - цілий світ відтінків комічного. В фундаменті і гумору, і сатири лежить особлива форма естетичного ставлення до дійсності - комедійне відношення. Залежно від естетичних властивостей об'єкта і цілей суб'єкта, комедійне ставлення до дійсності може бути поділеним на такі види: сатиричним і гумористичним. Ю. Б. Борев дає такі визначення поняттям гумор і сатира: «Слово «гумор» вживається, перш за все, в значенні «почуття комічного». В такому сенсі сатирик не може обійтися без гумору. Інше значення цього слова «доброзичлива насмішка». В цьому значенні гумор є одним з відтінків сміху і відрізняється від сатири, іронії і сарказму. Саме слово «сатира», як і слово «гумор», має два значення. В першому випадку поняття «сатира» має значення певного роду художніх творів, у другому ж- особливий вид сміху або висміювання, його відтінок, особливий тип емоційного, гостро критичного ставлення (сатирична насмішка, викриття і таке інше)» (Воробйова, 2007, с. 206).

Літературний енциклопедичний словник за ред. В. М. Кожевнікова і П. А. Миколаєва дає таке визначення сутності іронії, гумору і сатири: «У синкретичному сміхові потенційно або в зародковому вигляді закладені багато видів комічного, які відокремлюються потім в ході розвитку культури. Це перш за все іронія і гумор, протилежні за «правилами гри». В іронії смішне ховається під маскою серйозності, з переважанням негативного або ще навіть глузливого ставлення до предмета висміювання; а в гуморі - серйозне криється під маскою смішного, зазвичай з переважанням позитивного відношення. Серед усіх видів комічного гумор відзначається характером «світоспоглядання» та «світокритикування», а також складністю тону в оцінюванні життя. Навпаки, викривальний сміх сатири, предметом якого служать пороки та недоліки, властиві об'єкту висміювання, відрізняється цілком певним негативним, викриваючим тоном своєї оцінки» (Воробйова, 2007, с. 208).

Дехто вважає, що іронія - це щось середнє між гумором і сатирою. Тобто іронія апріорі є більш агресивною, ніж гумор, але менш активною, соціально забарвленою і образливою, ніж сатира.

2.5. Іронія, як вважає більшість дослідників (Ю. Б. Борєв, Б. О. Дземідок, О. П. Срмакова, Є. М. Кононенко, Д. П. Ніколаєв, І. Пасі, В. М. Півоєв і ін.), входить в число основних понять культури будь-якого народу і має багатовікову історію і велику кількість тлумачень. Вона знаходить своє втілення у великій кількості різноманітних явищ, вона то виступає в ролі одного з стилістичних прийомів, то претендує на статус філософської категорії. За свою багатовікову історію іронія втілювала стільки форм, що навіть до наших днів так і не з'явилося такої класифікації, яка охопила би всю палітру проявів іронії і знайшла б ті критерії, які дозволяють достатньо чітко віддиференціювати ï від суміжних категорій. «Жодна 3 існуючих теорій 
іронії не здатна повністю відрізнити іронічне висловлювання від НЕ іронічного» (Білецька, 2016, с. 25). Існує навіть термін «іронологія».

В сучасному мовознавстві існує дуже мало робіт, які стосуються естетичного аспекту іронії. Іронія як текстова категорія (інструмент стилістики), реалізуючись лінгвістичними засобами, дуже тісно пов'язана з екстралінгвістичними моментами, такими як соціальна позиція автора, його біографія, його соціальний статус, етичні та моральні принципи, філософськополітичні течії епохи і т. і.). «В останні роки міжособистісна комунікація привертає до себе особливу увагу лінгвістів, ставляться питання щодо впливу на процес взаємодії між людьми екстралінгвістичних і психологічних факторів. Все більше і більше підсилюється інтерес до іронії як до одного з важливих атрибутів мовної поведінки, що залежить від дотримання чи порушення певних етичних норм, від індивідуальних особливостей учасників спілкування і від специфіки ситуаційної взаємодії » (Срмакова, 2007, с. 219).

2.5.1. Перша згадка і використання терміну «іронія» 3'явилося в грецькій літературі у $\mathrm{V}$ ст. до н. е. Це слово спочатку означало обман, знущальне удавання або глузування, яке мало на меті висміяти кого-небудь. Однак скоро іронія в античній філософії та естетиці набула глибшого й ширшого значення, а пізніше стала чи не найголовнішим iï інструментом, а також зброєю багатьох філософів та мислителів проти циніків та нігілістів усіх епох. Платон визначав iï як життєву позицію грецького мислителя Сократа, який у невимушеній бесіді відкривав співрозмовникові і його власну обмеженість, і удавану значимість того, перед чим усі звикли схилятися. Іронія набуває статусу своєрідного ставлення особистості до світу в ті епохи, коли руйнуються усталені уявлення, а їм на зміну поступово приходять нові. Іронія має елемент приниження і знецінення, а також заперечення зображуваного, але водночас вона і загострює трагізм, тобто містить «своєрідну діалектику заперечення: удавано стверджує застарілі цінності і реалії, розвінчуючи їхню незначущість й нікчемність» (Білецька, 2016, с. 27).

Формально-логічну специфіку іронії дуже вдало описував у своїх роботах О. Лосєв: «Іронія на відміну від обману не просто приховує істину, але і виражає іiі, тільки особливим інакомовним чином. Іронія виникає тоді, коли я, бажаючи сказати «ні», кажу «так», і водночас це «так» я кажу виключно для вираження і виявлення мого щирого «ні». [...] Моє «ні» не залишається самостійним фактом, але воно залежить від вираженого «так», потребує його, стверджує себе в ньому і без нього не має жодного значення» (Білецька, 2016, с. 29).

Іронічний ефект за своїм емоційним наповненням та прагматичним спрямуванням може досягати різних цілей:

1) представлення об'єкта іронії у безглуздому вигляді;

2) дискредитація зображуваного;

3) підвищення серйозності тону;

4) підвищення симпатії до об'єкта іронізування (Білецька, 2016, с. 28).

Б. Дземидок вважає іронію «перехідним пунктом» між гумором і сатирою. Зважаючи на це, дослідник виділяє три повністю відмінні форми комізму: гумористичний, сатиричний $\mathrm{i}$ проміжний, який називає насмішкувато-іронічним (Калита, 2013, с. 24). Крім того Б. Дземидок розрізняє певні «засоби» висловлювання, або техніки створення комізму, і вважає, що іронія, разом із дотепом, насмішкою, гротеском, травестуванням, також одним із різновидів техніки комічного, яка може використовуватися як сатирою, так і гумором (Калита, 2013, с. 24). С. Походня розглядає іронію як форму «оцінного, критичного, емоційного освоєння дійсно- 
сті» (Калита, 2013, с. 25), тобто вважає її повноправною формою комічного, разом із сатирою та гумором (Калита, 2013, с. 25).

Отже, можна стверджувати, що у філософсько-естетичному аспекті вивчення іронії на сьогоднішній день сформовано три основні підходи до визначення статусу іронії серед інших категорій комічного: перший підхід визначає іронію як інструмент комічного, основними формами якого є сатира і гумор. За допомогою іронії може досягатися як сатиричний, так і гумористичний ефект, тобто вона може називатись проміжним пунктом між гумором - доброзичливим висміюванням, і сатирою - жорстоким глузуванням. Наступний підхід кваліфікує ії як проміжну форму між сатиричним і гумористичним відображенням світу. Найбільш логічним здається останній підхід, де іронія - це рівнозначна форма комічного, яка співіснує на одному рівні з сатирою та гумором, оскільки є цілий ряд ознак, що відрізняють її від інших форм комізму (Калита, 2013, с. 31).

Іронія меншою мірою, ніж інші форми комічного, залежить від несподіванки і від повторення не зникає. Вона в найбільш поширеній формі приписує об'єкту неіснуючі позитивні якості і в зв'язку з ними дає йому позитивну оцінку, але через натяк, контекст ситуації вказує на удаваність такого твердження.

3 іншого боку, існує думка, що іронія таки стоїть осторонь від інших засобів створення комічного. Подібно до всіх інших позитивних емоцій реакція на комічне виникає тоді, коли інформація, яка надходить 3 навколишнього середовища і веде до зростання ймовірності задоволення якоїсь потреби, перевищуючи раніше існуючий прогноз. Серед потреб при продукуванні іронічних дотепів і реакції сміху на них психологи виділяють наступні: потреба в почутті зверхності (А. І. Розов), прихована агресія (Адлер, Лоренц), прагнення до задоволення і компенсація сорому, страху й відрази (Фрейд). Таким чином, від ступеня вираженості актуальної потреби може залежати і ступінь вираженості реакції сміху на гостре висловлювання (Воробйова, 2007, с. 204).

За даними психологічних досліджень, для виникнення реакції сміху на гумористичне висловлювання необхідні конкретні умови. Перш за все, воно повинно заперечувати те, що очікувалося в певіній ситуації, повинно суперечити загальноприйнятим уявленням про ситуацію так званий ефект «обманутого очікування», i, по-друге, необхідна наявність почуття зверхності і власної захищеності. Іронія ж для такої реакції вимагає ефекту присутності і ще інших умов (Воробйова, 2007, с. 204).

Відомо, що не завжди іронія викликає реакцію сміху, тобто не завжди вона є проявом комічного. Деякі дослідники називають її скоріш видом мовленнєвої агресії або засобом мовленнєвої помсти, яка, тим не менш, зовні зовсім не порушує принципів ввічливості. У такому випадку іiі можна назвати завуальованою агресією (Воробйова, 2007, с. 205). Відзначається також, що іронізувати з приводу особистих якостей людини або якихось подій дорівнює знеціненню їх важливості. Отже, неможливо сміятися над людьми, які користуються справжнім авторитетом і повагою, а також явищами, що ввикликають шанобливе ставлення, тобто над тим, що вже отримало підвищену оцінку і не може бути знеціненим одразу ж. Саме тому іронічне висловлювання може викликати у слухача не посмішку і сміх, а навпаки осуд або презирство до її автора, навіть якщо іронія звернена не на самого слухача, а на адресу третьої особи (Воробйова, 2007, с. 206). 
2.5.2. Функція іронії, на думку деяких учених, не є обмеженою, тобто іронія має на меті не лише створення комічного ефекту. Практично усі словники наголошують на властивості іронії виражати глузування під виглядом схвалення або похвали. «Кардинальна мета іроніїце насмішка, хоча не кожне іронічне висловлювання містить насмішку» (Петрова, 2018). «Мета іронії - не смішити і не розважати, а, навпаки, підкреслити всю серйозність, часом навіть трагічність положень і ситуацій. Насмішка створюється тим, що оголюється безглуздість того, що відбувається. Іронія в творі може ставитися до окремих персонажів; письменники часто використовують іiі для створення певної «характерності». За допомогою іронії може бути передано авторське судження про дійсність в цілому. В такому випадку принцип іронії стає стрижневим, на ньому будується весь твір» (Петрова, 2018). Іронія може поділятись на м'яку або добродушну, глузливу і сарказм (тобто іронізування з деяким знущанням) (Петрова, 2018).

На сучасному етапі дослідження іронії учені дійшли висновку, що іронія - це окрема категорія, пов'язана з світоглядом, філософією автора. О. Г. Петрова у своїй статті наводить таку цитату про погляд на іронію І. Н. Іванової: «Іронія має лише опосередковане відношення до естетичної категорії комічного, і багатьом її типам - зокрема, драматичному, пізньоромантичному, екзистенціальному, символістському - притаманний швидше трагічний, ніж комічний тон. Негативна оцінність дійсно є необхідним компонентом іронії, але ступінь негативності в оцінці об'єкта іронії може бути різним: від різкого неприйняття (тоді іронія наближається до сарказму, сатири, інвективи) до простої стриманості і поміркованості» (Петрова, 2018).

Стає очевидним той факт, що іронія розкриває, підсилює і розвінчує «удаваність», ницість і беззмістовність предмета, який зовні ще зберігає свою величину і значимість. Іронія, поєднуючи в собі обидві сторони, зближається з гумором і з сатирою. Крім того, ця двопланова амбівалентність сміху ускладнюється в іронії двоплановістю іронічного вираження: ціннісна структура іронії містить зовнішнє ствердження, внутрішнє заперечення і кінцеве ствердження, а також характеризується здатністю до двоспрямованості: на об'єкт і на себе (на суб'єкт). Така триплановість характерна лише для іронії (Петрова, 2018).

\section{3. Висновки}

Узагальнюючи проаналізовані підходи, можна дати наступне визначення поняття іронії як філософсько-етичного феномена. Іронія - це форма комізму, яка виражається в емоційнооцінному естетичному суб'єктивованому ставленні до дійсності, характеризується триплановою структурою вираження, при відносній рівноправності цих планів, амбівалентністю, здатністю до двоспрямованості і специфічним емоційним переживанням. Як і інші форми комічного, іронія як форма критики об'єкта грунтується на певному уявленні про ідеал, про вищу гармонію (Петрова, 2018).

Тобто оцінка іронії і її сприйняття як комічного залежить в більшій мірі від способу і ситуації іï вживання (включаючи і невербальні прояви), і від того, на кого вона спрямована. Тому іронія - це особливий засіб комізму, який може мати різноманітну зворотню реакцію - від сміху, до образи і обурення. Градус вираженості цієї реакції залежить не тільки від наявності або відсутності почуття гумору у слухача, бо, скоріше за все, і інші риси особистості слухача / читача відіграють в цьому не останню роль.

Отже, іронія - це складне і суперечливе явище. У соціальній свідомості, 3 точки зору норм і правил поведінки, за нею закріпився негативний образ. У той же час вона дуже приваблива для людей і приносить велике задоволення тим, хто її використовує. 


\section{СПИСОК ЛІТЕРАТУРИ \\ (REFERENCES)}

Arutiunova, N. D. (2007). Esteticheskii i antiesteticheskyi aspekty komizma. Lohycheskii analiz yazyka. Yazykovye mekhanyzmy komizma. M. : Yzdatelstvo «Indryk». 5-17.

Arutiunova, N. D. (2007). Logicheskiy analiz yazyika. Yazyikovyie mehanizmyi komizma. M. : Izdatelstvo «Indrik».

Biletska, O. O. (2016). Ironiia yak fenomen kultury. Kultura i mystetstvo u suchasnomu sviti. 17. 25-34.

Ermakova, O. P. (2007). Ironiya - lozh - shutka. Logicheskiy analiz yazyika. Yazyikovyie mehanizmyi komizma. M. : Izdatelstvo «Indrik». 219-229.

Kalyta, O. M. (2013). Zasoby ironii v malii prozi. Monohrafiia. K. : Vydavnytstvo NPU imeni M. P. Drahomanova.

Petrova, O. G. (2016). Ironiya i raznyie tipyi komicheskogo v hudozhestvennom tekste.

Shatunovskiy, I. B. (2007). Ironiya i ee vidyi. Logicheskiy analiz yazyika. Yazyikovyie mehanizmyi komizma. M. : Izdatelstvo «Indrik». 340-372.

Vorob'eva, K. A. (2007). Spetsifika ironii sredi drugih yazyikovyih sredstv komizma. Logicheskiy analiz yazyika. Yazyikovyie mehanizmyi komizma. M. : Izdatelstvo «Indrik». 201-206.

Стаття надійшла до редакиії 29.11.2019 